\title{
Management of land reclamation quality for agricultural use in opencast mining
}

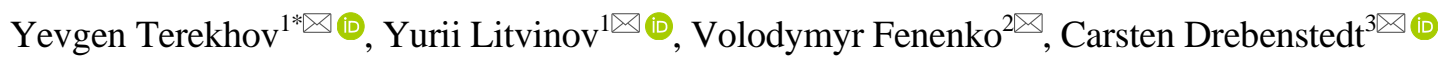 \\ ${ }^{1}$ Dnipro University of Technology, Dnipro, 49005, Ukraine \\ ${ }^{2}$ Prydniprovska State Academy of Civil Engineering and Architecture, Dnipro, 49600, Ukraine \\ ${ }^{3}$ TU Bergakademie Freiberg, Freiberg, 9599, Germany \\ *Corresponding author: e-mail terehoff@t-online.de, tel.+380930405918
}

\begin{abstract}
Purpose. Theoretical substantiation of principles and development of recommendations for the choice of technological variant to form the quality of lands of technogenic origin, which would ensure rational spending of funds allotted for reclamation and preservation of the reclaimed lands suitability for agricultural use with the highest requirements for agrophysical soil characteristics.

Methods. The following methods were used in the process of the research: the method of theoretical generalization and systematization (to determine the characteristics peculiar to the formation of qualitative characteristics of man-made soil using mechanization of reclamation works), analytical (to determine the factors influencing the effectiveness of land reclamation in opencast mining), comparison (to analyze the efficiency of different versions of reclamation works mechanization).

Findings. The influence of technical means of reclamation works mechanization on the quality of lands subject to restoration in conditions of opencast mining is analyzed. A methodological approach to the choice of mechanization of land reclamation works in respect to the indicators of the formed quality of technogenic agricultural lands as a factor of their monetary valuation and the level of costs for their reproduction is proposed. Recommendations for quality management of man-made lands by technical support of the process of their consumer properties formation, aimed at achieving a favorable ratio between quality and, accordingly, monetary valuation of man-made lands, on the one hand, and, on the other, - the cost of their reclamation.
\end{abstract}

Originality. A scientific and methodological approach to the choice of technical equipment for reclamation works is proposed, where two factors are considered: reclamation costs and quality of man-made lands, which allows to determine the priority of cost savings or land quality improvement according to the target criterion of reclamation works efficiency.

Practical implications. The obtained results are aimed at improving the methodological bases for management of the manmade lands reclamation process based on the choice of its mechanization means.

Keywords: land quality, reclamation costs, monetary valuation of lands, reclamation technology, reclamation efficiency

\section{Introduction}

\subsection{Statement of the problem}

The choice of rational technology for land reclamation in open cast mining is the matter of considerable scientific and practical importance in the field of environmental protection at any mining enterprise, since the land alienation for the needs of deposit development is associated with significant costs [1]. Mining enterprises, according to the law [2], are obliged to compensate for the quality loss of allotted and reclaimed lands, to spend money for servicing and maintenance of technological equipment, land reclamation, and compensation to the landowners for the loss of agricultural production. Increase in the financial responsibility level of any mining enterprise for land usage without understanding its effectiveness causes dissemination of practice when the requirements concerning the quality and volumes of land restoration are treated only formally.
A mining enterprise is interested in improving the reclamation results only if the land quality enhancement rate outstrips the increase in reclamation cost [3]. Therefore, it is necessary to choose such mechanization tools and technology of mining reclamation which will allow to create high fertility soils (primarily for agricultural use), without entailing big production costs for reclamation and payments to compensate agricultural enterprises losses [4].

\subsection{Literature review}

Scientific community is paying more and more attention to the quality results of land reclamation in open cast mining. In particular, A. Shapar [5] investigated the problem of loss and clogging of the humus layer in the process of mining operations as a major technological factor in the formation of technogenic lands quality. Scientists in [6] considered the problem of choosing the rational mechanization techniques 
as a means to improve the quality of disturbed lands reclamation process and reducing its cost.

In the study [7], it is noted that the process of justifying field development technologies aimed at preserving the quality of lands disturbed by mining is not yet completed.

The work [8] focuses on the fact that mining produces a strong impact on the architecture of natural landscapes. The example of one of the largest mining areas in East Germany is used to analyze the land use basic principles and outline possible scenarios for further lines of disturbed lands restoration. It is emphasized that land restoration must be undertaken in the aspects that are topical for the specific purposes of a particular locality. In studies [9], [10] the relationship between the degree of environmental degradation and the development techniques, mechanization, geometry and location of the deposit has been examined. Thus, due to the rational choice of mining technology it is possible to reduce the negative impact of mining on the environment.

The authors of [11], [12] emphasize that timely restoration of disturbed lands in accordance with the requirements of the law is an urgent obligation of the subsoil user. Reclamation of previously mined quarry space is one of the most important tasks of a mining company. For the effective restoration of disturbed lands, it is necessary to adhere to the principles of simultaneity, rather than sequence of processes at different stages of mining life cycle. Researchers [13], [14] put the stress on the destructive impact of inefficient mining technologies on the ecology of mining regions.

It is known that mining industry is the main cause of natural environment disturbance and technogenic problems. Interaction of disturbed and technogenic massifs with natural geological environment leads to the development of such negative processes as landslides, flooding and desertification of territories. In turn, these negative processes lead to the emergence of secondary disturbances in the natural environment - directly in disturbed and technogenic massifs - additional sedimentation and deformation of rocks, down warping etc. [15]. The scientific literature focuses on the environmental consequences of the opencast mining development, economic and technological problems caused by the destructive impact of mining enterprises on the environment [16][20]. Scientists stress the need to use reliable criteria for assessing the negative effects of mining on the condition of the affected land [21][23].

The key factor in the cost of land restoration after open cast mining is the choice of remediation area and the technology of its reclamation. If land rehabilitation is mainly driven by legal requirements and market factors, reclamation technology is a tool of targeted influence on the overall level of mining enterprise costs related to land alienation. Thanks to the selected reclamation technology, it is possible to determine such quality indicators of technogenic soil that are most suitable for its further use.

So, suitability of lands for agricultural development is determined by the following indicators: capacity of the bulk fertile soil layer, cm; the content $(\%)$ and the stock (t/ha) of humus in the bulk soil; the content of physical clay in the bulk and underlying rock, \%; average density of black earth mass in a meter-thick bulk layer; the degree of salinization of the black earth layer and the underlying rock. However, the most important is the quality and content of humus in the soil of agricultural land [3]. Accordingly, the technical means of land reclamation must be primarily chosen in terms of the land quality assurance by these two indicators.
In real conditions, the removal of the black earth layer occurs on a complex, uneven surface, the shape of which depends on many factors. The main ones are the following: the shape of the working body cutting edge; specifics of its movements; design features and operational characteristics of reclamation equipment, etc.

When making a rational decision on the formation of quality technogenic land, it is necessary to start from the effect that the mining enterprise wants to achieve from the reclamation. If the priority is to achieve the lowest cost of reclamation works, they require the technology based on the use of the rotor complex in the development of advanced ledge. However, this technological solution will lead to the production of man-made lands with poor quality indicators. If the quality of land is a priority, more expensive technologies should be used. However, it is necessary to take into account payments for compensating losses of agricultural production, which will be higher with less expensive reclamation technology.

The research showed that using draglines for soil stripping causes biggest losses and worst soil contamination approximately $50-52 \mathrm{~mm}$ of the humus layer thickness. The least losses $(18 \mathrm{~mm})$ are associated with stripping black earth contacting barren rock by single-bucket excavators, while the least impoverishment $(17 \mathrm{~mm})$ is related to using bulldozers or scrapers for that purpose. Utilizing single-bucket loaders contributes to minimization of losses and soil contamination while stripping the surface of the opening bench [5].

Thus, certain means of mechanization and technology of mining reclamation determine the fertility (quality) of reclaimed lands as for their individual properties and as a whole. Crop yields intensively grow until a certain thickness of the bulk humus layer is reached. Further growth, although it leads to an absolute increase in yield, is characterized by the effect of marginal productivity. Therefore, when choosing the means for mechanization and technology of the mining stage of dumps reclamation in a particular quarry, one should control their suitability for the application of the required capacity and uniformity of the black earth layer. This should be taken into account when choosing the technology of reclamation works, provided the creation of man-made soils which ensure the highest economic value of the reclaimed land resources [3].

A rational way (in terms of mechanization and technology) of used land restoration when returning it to landowners should provide for the achievement of the lowest production costs for mining reclamation. In addition to the costs directly related to the reclamation process itself, the costs of repairing the reclaimed plots should be taken into account. As a result of reclamation works with deviations from the project, which leads to low quality of these works, production costs for the reclamation itself can be reduced, but in the future there may be a need to spend more money on repairs.

Based on the above, the study of the problems related to the increase in the level of land conservation in conditions of opencast mining needs further development, which will reduce the environmental and economic loss from mining.

\subsection{Unresolved issues that are part of the overall problem}

Every mining company is interested in the introduction of production technologies that can simultaneously improve the quality of final products and reduce the level of disturbing natural resources that occur in the area of mining operations. 
Accordingly, this problem needs further elaboration. At the same time, among the environmental issues of extractive activity development, the most acute problem is the reproduction of lands destroyed by deposits development, not only in terms of disturbance area, but also in the context of their quality.

However, today the issue of improving the efficiency of land reclamation in conditions of opencast mining is not properly reflected in scientific works on land reclamation of man-made origin. The problem of choosing the means for mechanization of land reclamation works, which would allow simultaneous compliance with the target settings for the quality of reclaimed land and reasonable costs for its provision, remains unresolved. In this aspect, it is important to identify a set of equipment that can reduce the cost of reclamation, and equipment that can improve the quality of man-made soil. As a result, each of the criteria of land reclamation will increase its efficiency.

\subsection{Formulation of the aims of the article}

The study aims to determine the impact of mechanization during disturbed lands restoration on the soil quality and costs of moving rock mass within the working area of reclamation works, as well as to develop recommendations for choosing reclamation technology that allows to achieve a favorable ratio of costs and quality (monetary value) of agricultural land.

\section{Methods}

Achieving the aim of the study is based on the application of the following methods in a certain sequence: systematization - to justify the dependence of the quality of man-made lands on the use of various technical means of reclamation mechanization (at this stage used a tool to summarize research results of man-made lands); analysis - to assess the impact of the working area of the various technical means surface on the formation of the fertile layer of reclaimed land (used a tool to assess the main factors of technical means impact on soil quality); comparison - to determine the most appropriate technological version for land reclamation according to the criteria of soil quality formation and costs for its reproduction in conditions of horizontal mineral deposits (used a tool for evaluating the results of alternative technological schemes of reclamation according to the criteria of its efficiency).

The study of preserving the quality of technogenic lands was carried out using the example of manganese ore horizontal deposits of the Nikopol basin in conditions of Pokrovsky MPP activity.

At Pokrovsky MPP, when mining the ore bed, they mostly apply EKG-5 excavators; bulldozers (mainly with hydraulic dump control), Cat; draglines with small bucket capacity ESh-6/45. This equipment should be considered as basic in solving the research problem, and as a promising one - single-bucket wheel loader Cat $990 \mathrm{~K}$ and scraper $631 \mathrm{G}$.

\section{Results and discussion}

The choice of technology for reclamation of lands disturbed as a result of opencast mining is a problematic issue, which involves a significant negative impact on the environmental activities of a mining company, as the area of land alienation while using different technologies can vary significantly. The mining company will be interested in improving the results of reclamation only if these measures help to achieve a better ratio between the value of land and the cost of land formation of appropriate quality. Based on this, it is necessary to choose a technology for mining lands and their reclamation, which would ensure the formation of high quality soils with low costs for the mining company and payments to compensate losses of agricultural production.

Based on the above analysis, it is possible to determine the criteria for the selection of equipment and technology for reclamation of land disturbed in open mining, namely:

1) the creation of soils whose fertility rates which allow them to return to previous use;

2) savings on land reclamation and compensation for losses of agricultural production.

Analytically, this can be represented as follows:

$S C r=\left(C_{r e c}(B r)+C_{r e p}(B r)+B a \cdot u(B r)+K l(B r)\right) \rightarrow \min ,(1)$

where:

$\mathrm{SCr}$ - the cost of mining reclamation, $\mathrm{UAH} / \mathrm{ha}$;

$C_{r e c}(B r), C_{r e p}(B r), B a . u(B r), K l(B r)$ - production costs, $\mathrm{UAH} / \mathrm{ha}$, respectively for reclamation works, repair of manmade plots, cost of documentation needed for allotment of land and compensation of agricultural production losses as a function of the score $\mathrm{Br}$ of the bonus of man-made plots.

In order to achieve the objective Function (1) of land reclamation efficiency, the technical means and technology of the disturbed lands restoration are adopted considering the necessity to comply with the following conditions:

$$
\begin{aligned}
& M v=f(B r) \rightarrow \max ; \\
& B r=f(S C r) \rightarrow \max ; \\
& S C r=f(T) \rightarrow \min ; \\
& B r=f(T) \rightarrow \max ,
\end{aligned}
$$

where:

$M v$-monetary valuation of the reclaimed land plot, $\mathrm{UAH} / \mathrm{ha}$;

$\mathrm{T}, \mathrm{Br}$ - the technology of recultivation and the bonus of technogenic soil, which can be created by a complex of equipment using this technology.

Separate stages of reclamation can be carried out using different technical means that have different design characteristics. These means determine a particular option of mining reclamation. The solution of the problem realized in the objective function $S C r=f(T) \rightarrow$ min is related to the gradual review of all possible options of land reclamation technology.

Based on this approach, it is recommended to choose equipment and technology of reclamation works for the conditions of manganese quarries of Pokrovsky MPP according to the lowest cost criterion related to the objective Function (1). Three schemes of mining remediation have been considered, two of which are already applied to opencast mining of horizontal deposits, and one is proposed by the authors on the basis of the research [24].

Scheme 1 (Fig. 1a). Black earth and potentially fertile loam are removed by scrapers 1 which mix and stack these rocks on the surface of dump 9. The surface of the black earth and potentially fertile layer (PFL) is leveled by bulldozers 2 , and the dump ridges are cut by draglines 3 . The deposit is opened according to the complex transport less scheme using mining dragline 4 and dumping dragline 5 . 
(a)

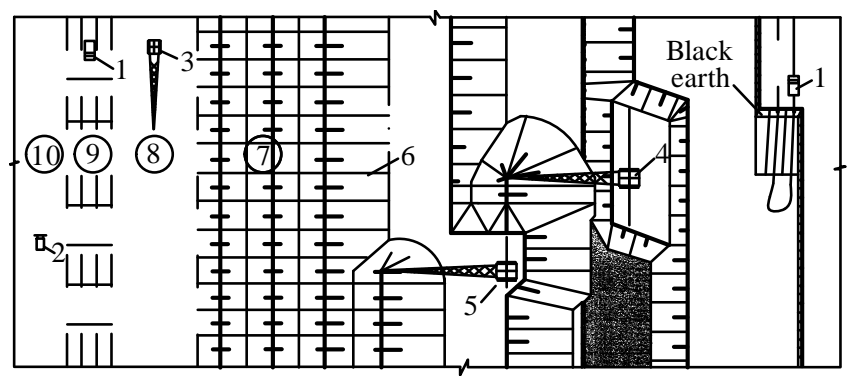

(b)

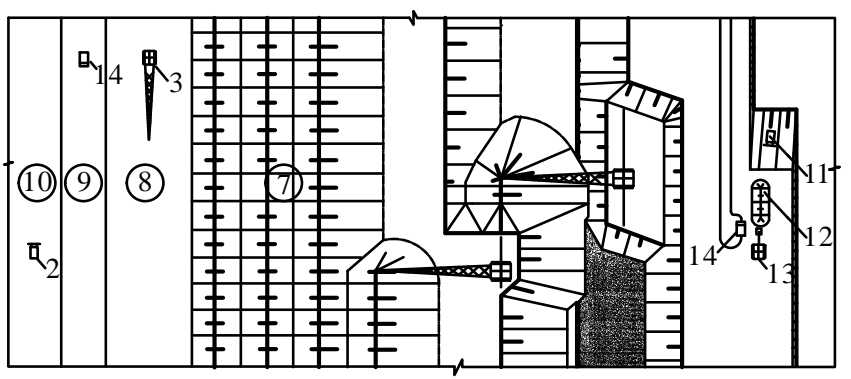

(c)

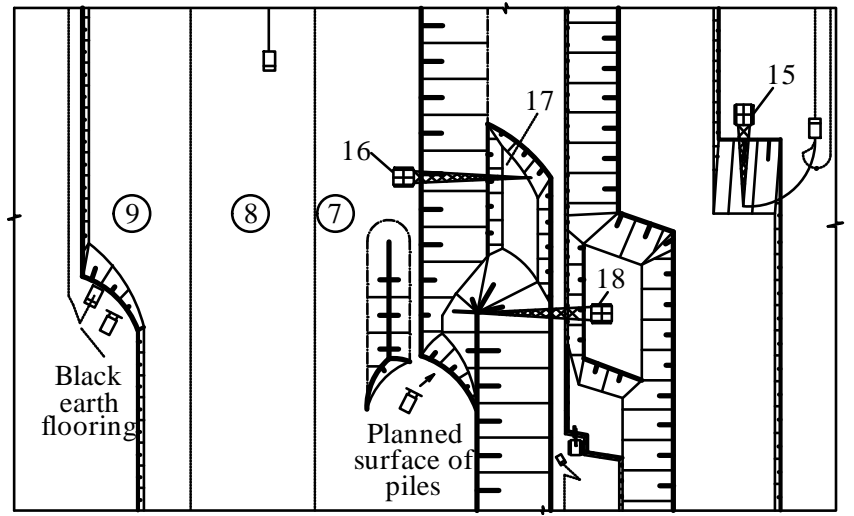

Figure 1. Scheme of mining reclamation: (a) using scrapers for stripping and removing of black earth and PFL; (b) using bulldozers and motor vehicles for stripping and removing of black earth and PFL; (c) using dragline and motor vehicles for stripping and removing of black earth and PFL; 1-scraper; 2-bulldozer; 3-5-draglines; 6-internal dumps; 7-the surface of the internal dumps to be settled; 8 -smooth surface of the internal dump; 9-the surface with PFL; 10-the reclaimed surface; 11-the bulldozer; 12 -the pile with black earth; 13 -the excavator mechanical shovel; 14-the dump truck; 15, 16, 18 -draglines; 17 - advance trench

Dragline 5 forms the upper tier of the inner dump leaving a large area with ridges 6 . The designated area 7 is settling for some time. After a considerable time lag the dump surface of the plot 8 is leveled, and then the PFL is appled to plot 9 , and after a certain settling time a layer of black earth is also applied. The final alignment of the surface occurs on plot 10. On the overhanging ledge, the front of the works on black earth removal should go ahead of the front of works on the removal of potentially fertile rocks, and on the dump - on the contrary, the front of works on PFL application should go ahead of the front of works on the formation of the black earth layer. For this, section 9 is divided into appropriate blocks.
Scheme 2 (Fig. 1b). The black earth is removed by bulldozer 11 , stacking it into piles 12 . From here, the excavator 13 ECG-5A reloads the black earth into truck 14, which transports and stacks it on the quarry bench.

The layer of potentially fertile rocks is removed and piled on the surface of the cutting ledge also by bulldozers 11 and loaded into the dump trucks 14 also by mechanical shovels 13. The dump trucks deliver the PFL directly to the surface of the dump section 9 due to the fact that it is already laid with the black earth layer. The area of the dump surface 9 is pre-aligned with dragline 3 in section 8 . Section 9 is prepared for the application of the black earth layer (this area should be covered with a layer of potentially fertile rocks and should be settled for a certain period of time), then the black earth is directly delivered to the prepared section 9 and finally aligned by bulldozer 2 on section 10 .

Scheme 3 (Fig. 1c). The black earth is stripped by dragline 15 and loaded directly into motor vehicle, which transports it to the dump surface of section 9, where a layer of potentially fertile rock is pre-deposited on section 8 .

In order to avoid the formation of ridges on the surface of the internal dumps on section 7 , a new technological solution was proposed based on the creation of an advance trench as a working in the dump floor [24]. Due to this approach, the rock settles with already levelled surface of the internal dump, which greatly simplifies and accelerates the process of the site restoration. The process of aligning the surface of section 7 of the internal dump is implemented as follows. The opencast bench covering the ore bed is divided along the height into the upper and lower sub-benches by the intermediate platform. The bench is developed by two dragline excavators, one of which, located on the surface of the internal dump 16, forms an advance trench working in the floor of dump 17 by downward scraping.

The second excavator 18 , located on the intermediate platform, fulfills the upper and lower sub-benches by upward and downward scraping and pours overburden into the internal dump and the advance trench 17 . The peculiarity of this scheme is that the rocks from the advance trench are used to fill in the gap between the ridges, thus forming a surface without significant variations in height.

In accordance with the lowest total costs, scheme 3 is the most appropriate. The absence in the technological chain of the process associated with cutting off the dump ridges increases the application efficiency of this scheme. This approach also results in cheaper final alignment, since the surface of the internal dump is almost flat, and therefore the equipment for the application of PFL and black earth works with greater productivity. Scheme 3 involves separate transportation of black earth by dump trucks and loam (by conveyors) onto the surface of the dump. Indicators of losses and impoverishment of reclaimed soils are taken according to Table 1.

Table 1. Comparative technological performance indicators of mine reclamation schemes

\begin{tabular}{lccc}
\hline Scheme of mining-technical reclamation & 1 & 2 & 3 \\
\hline $\begin{array}{l}\text { Thickness of the black earth layer } \\
\text { lost during contact stripping, mm }\end{array}$ & 28 & 25 & 52 \\
\hline $\begin{array}{l}\text { Thickness of the layer of the underlying } \\
\text { clogged rocks during soil stripping, mm }\end{array}$ & 17 & 17 & 50 \\
\hline $\begin{array}{l}\text { Overall bonus score } \\
\text { tosts of reclamation, } \\
\text { thousand UAH per 1 ha }\end{array}$ & 320 & 280 & 250 \\
\hline
\end{tabular}


The analysis of technological features characterizing mechanization of reclamation works allows to establish the following: given the unsatisfactory technology of contact stripping and the formation of the underlying layer (bonus 70), scheme 3 is not perfect in terms of uniform removal of the humus profile, but it can significantly reduce the cost of reclamation. This makes it possible for managers of mining enterprises to choose the scheme of mineral resources mining, using the criteria of technogenic lands quality and the cost of their restoration.

According to the calculations of the authors, using the data of production costs for the technological stages of mining reclamation (Table 2), we can determine the following.

Table 2. Production costs of mining reclamation depending on the flow chart

\begin{tabular}{|c|c|c|c|c|c|c|}
\hline \multirow{2}{*}{ Reclamation work } & \multicolumn{2}{|c|}{ Scheme 1} & \multicolumn{2}{|c|}{ Scheme 2} & \multicolumn{2}{|c|}{ Scheme 3} \\
\hline & equipment & $\mathrm{UAH} / \mathrm{m}^{3}$ & equipment & $\mathrm{UAH} / \mathrm{m}^{3}$ & equipment & $\mathrm{UAH} / \mathrm{m}^{3}$ \\
\hline $\begin{array}{l}\text { Stripping of black earth } \\
\text { PFL }\end{array}$ & scraper & 2.8 & $\begin{array}{c}\text { bulldozer and } \\
\text { mechanical shovel }\end{array}$ & $\begin{array}{l}1.6 \\
2.4\end{array}$ & dragline & 2.0 \\
\hline $\begin{array}{l}\text { Transporting black earth } \\
\text { PFL }\end{array}$ & scraper & $\begin{array}{l}7.6 \\
8.0 \\
\end{array}$ & dump truck & 7.8 & dump truck & 7.8 \\
\hline $\begin{array}{l}\text { Stacking black earth } \\
\text { PFL }\end{array}$ & & & bulldozer & 1.6 & & \\
\hline Cutting off dump cones & dragline & 3.2 & dragline & 3.2 & & \\
\hline $\begin{array}{l}\text { Dump surface alignment } \\
\text { PFL } \\
\text { Black earth }\end{array}$ & bulldozer & 1.6 & bulldozer & 1.6 & bulldozer & 1.2 \\
\hline
\end{tabular}

The decision to implement a specific technological scheme of land reclamation will depend on the land restoration priorities in each case - either reducing costs or improving quality. Schematically, the distribution of relevant technologies can be represented as a graph of Figure 2. Technological solutions aimed at ensuring the maximum score of land quality (B1), as a rule, require increased costs $\mathrm{C} 1$, and vice versa - reducing the requirements for land quality (score of quality B2) will allow the use of technological schemes with more productive equipment, but less suitable in terms of preventing losses of land quality indicators.

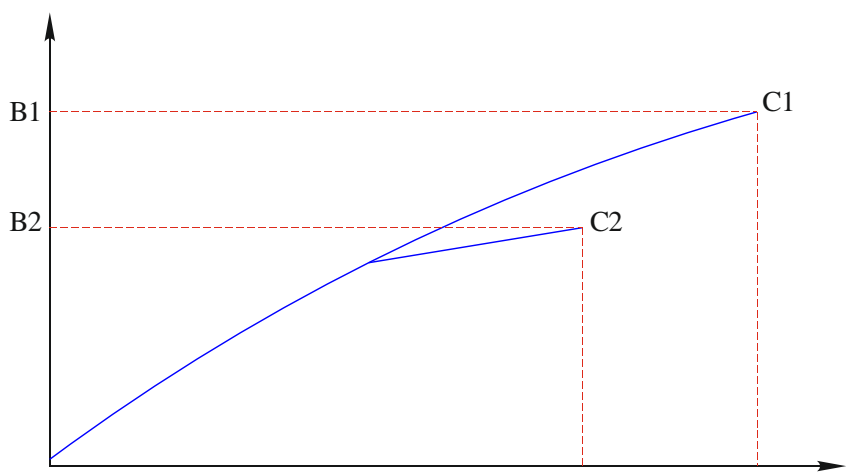

Figure 2. Comparison of the effectiveness of land reclamation technologies: B1, B2 - score of quality; C1, C2-costs

If the condition $\mathrm{B} 1 / \mathrm{B} 2<\mathrm{C} 1 / \mathrm{C} 2$ is met, then introduction of technology 1 is appropriate for technology 2 in terms of ensuring the maximum efficiency of land reclamation in conditions of opencast mining. This will, to a greater extent, stimulate the management of mining enterprises to use technological means of land reclamation, focused on the creation of high quality lands in terms of their intended use.

\section{Conclusions}

It has been determined that the structure of land reclamation technology in the conditions of open cast mining significantly influences the qualitative state of technogenic lands in terms of loss avoidance and soil impoverishment. Thereby preventing the technogenic soil quality degradation accor- ding to the requirements of subsequent land use by applying the appropriate complex of reclamation works mechanization ensures the suitability of the land for wider economic use, the stability of productive properties, and, consequently, the formation of higher monetary valuation. To this end, the methodological approach to the selection of technological equipment based on the criterion of minimizing the land reclamation costs, while respecting the restrictions on the qualitative state of technogenic soil required for its agricultural use, is proposed.

It is established that for the best selective removal of the black earth layer, it is necessary to use equipment characterized by less fluctuation of the cutting edge of the working body relative to the technological surface. However, given the cost of land reclamation, a mining enterprise should independently determine which option of reclamation works mechanization is acceptable, based on the desired ratio of the cost of technogenic lands and the cost of their reproduction. Increasing land value and reducing reclamation costs (including land repairs) contribute to improving its restoration efficiency. Considering restrictions on the quality of technogenic soil for agricultural use, it is determined that the use of draglines, dump trucks and bulldozers without intermediate piling of PFL will allow to achieve the lowest costs of reclamation, and therefore to increase its efficiency.

\section{Acknowledgements}

The authors extend their gratitude to the professor, Ph.D. Prokopenko Vasyl Ivanovych for the phase consultations during preparation of the present scientific article.

\section{References}

[1] Litvinov, Yu.I. (2018). Tekhnolohichni zasady rozkryttia ta rozrobky horyzontalnykh kariernykh poliv pry obmezhenomu porushenni pryrodnykh resursiv. $\mathrm{PhD}$ Thesis. Dnipro, Ukraine: Dniprovska politekhnika, $215 \mathrm{~s}$.

[2] Zemelnyi Kodeks Ukrainy. (2020). Kyiv, Ukraina: Verkhovna Rada Ukrainy.

[3] Litvinov, Y., Terekhov, Y., \& Fenenko, V. (2019). Improvement of open field development technology as a factor in the formation of quality and market value of reclaimed land. E3S Web of Conferences, (123), 01045. https://doi.org/10.1051/e3sconf/201912301045 
[4] Prokopenko, V.I., \& Mormul, T.M. (2015). Naukovo-prykladni zasady stvorennia zemlezberihaiuchykh tekhnolohii vidkrytoi rozrobky horyzontalnykh rodovyshch. Visnyk NTUU "KPI". Seriia "Hirnytstvo", (28), 49-62.

[5] Shapar, A.H., \& Belyakov, V.M. (1991). Povyshennya polnoty vyemky poleznykh iskopamykh na karyerakh. Kyiv, Ukraina: Naukova dumka.

[6] Vondráčková, T., Voštová, V., \& Kraus, M. (2017). Mechanization for optimal landscape reclamation. IOP Conference Series: Earth and Environmental Science, (95), 022042. https://doi.org/10.1088/17551315/95/2/022042

[7] Prokopenko, V.I. (2015). On assessment criteria of efficiency of land resources saving in surface mining. Economic Bulletin of the National Mining University, (2). 183-189.

[8] Larondelle, N., \& Haase, D. (2012). Valuing post-mining landscapes using an ecosystem services approach - An example from Germany. Ecological Indicators, (18), 567-574. https://doi.org/10.1016/j.ecolind.2012.01.008

[9] Nuric, A., Nuric, S., \& Brcaninovic, M. (2014). Redevelopment of mining area. Quaestus Multidisciplinary Research Journal, 267-278.

[10] Gorova, A., Pavlychenko, A., \& Borysovs'Ka, O. (2013). The study of ecological state of waste disposal areas of energy and mining companies. Annual Scientific-Technical Collection - Mining of Mineral Deposits, 169-172. https://doi.org/10.1201/b16354-29

[11] Asr, E.T., Kakaie, R., Ataei, M., \& Tavakoli Mohammadi, M.R. (2019). A review of studies on sustainable development in mining life cycle. Journal of Cleaner Production, (229), 213-231. https://doi.org/10.1016/j.jclepro.2019.05.029

[12] Rysbekov, K., Toktarov, A., Kalybekov, T., Moldabayev, S., Yessezhulov, T., \& Bakhmagambetova, G. (2020). Mine planning subject to prepared ore reserves rationing. E3S Web of Conferences, (168), 00016. https://doi.org/10.1051/e3sconf/202016800016

[13] Kuter, N., \& Kuter, S. (2015). Land cover/use change assessment using maximum likelihood and support vector machines algorithms in Tunçbilek coal mine area. Environment and Ecology at the Beginning of $21^{s t}$ century (pp. 411-423). Sofia, Bulgaria: St. Kliment Ohridski University Press.

[14] Kivinen, S. (2017). Sustainable post-mining land use: are closed metal mines abandoned or re-used space? Sustainability, 9(10), 1705. https://doi.org/10.3390/su9101705
[15] Bubnova, O. (2019). Prediction of changes in the state of the geological environment in the mining region. E3S Web of Conferences, (109), 00009. https://doi.org/10.1051/e3sconf/201910900009

[16] Gorova, A., Pavlychenko, A., Borysovs'ka, O., \& Krups'ka, L. (2013) The development of methodology for assessment of environmental risk degree in mining regions. Annual Scientific-Technical Collection - Mining of Mineral Deposits, 207-210. https://doi.org/10.1201/b16354-37

[17] Pavlychenko, A., \& Kovalenko, A. (2013). The investigation of rock dumps influence to the levels of heavy metals contamination of soil. Annual Scientific-Technical Collection - Mining of Mineral Deposits, 237-238. https://doi.org/10.1201/b16354-43

[18] Sobko, B.Yu., Lozhnikov, O.V., Haidin, A.M., \& Laznikov, O.M. (2016). Substantiation of rational mining method at the motronivskyi titanium-zirconium ore deposit exploration. Naukovyi Visnyk Natsionalnoho Hirnychoho Universytetu, (6), 41-48.

[19] Xu, X., Gu, X., Wang, Q., Gao, X., Liu, J., Wang, Z., \& Wang, X. (2018). Production scheduling optimization considering ecological costs for open pit metal mines. Journal of Cleaner Production, (180), 210-221. https://doi.org/10.1016/j.jclepro.2018.01.135

[20] Vuyeykova, O., Sładkowski, A., Stolpovskikh, I., \& Akhmetova, M. (2016). Rationalization of road transport park for the carriage of mining rocks in the open mines. Transport Problems, 11(1), 79-85. https://doi.org/10.20858/tp.2016.11.1.8

[21] Bangian, A.H., Ataei, M., Sayadi, A., \& Gholinejad, A. (2012). Optimizing post-mining land use for pit area in open-pit mining using fuzzy decision making method. International Journal of Environmental Science and Technology, 9(4), 613-628. https://doi.org/10.1007/s13762012-0047-5

[22] Litvinov, Y., Terekhov, Y., \& Fenenko, V. (2019). Improvement of open field development technology as a factor in the formation of quality and market value of reclaimed land. E3S Web of Conferences, (123), 01045. https://doi.org/10.1051/e3sconf/201912301045

[23] Terekhov, Y.V., \& Litvinov, Y.I. (2018). Eco-oriented management of manufacturing and supply activity of manganese ore raw materials supplier. Naukovyi Visnyk Natsionalnoho Hirnychoho Universytetu, (4), 166-174. https://doi.org/10.29202/nvngu/2018 4/20

[24] Prokopenko, V.I., Vesel, M.M., \& Litvinov, Yu.I. (2015). Sposib rozrobky ustupiv rozkryvnykh porid pry vydobutku horyzontal'noho plasta korysnoi kopalyny. Patent No. 109862, Ukraine.

\section{Управління якістю відтворення земель під сільськогосподарське використання в умовах відкритої гірничої розробки}

\section{Є. Терехов, Ю. Літвінов, В. Фененко, К. Дребенштедт}

Мета. Теоретичне обгрунтування засад та розробка рекомендацій щодо вибору технологічного варіанту формування якості земель техногенного походження, які б відповідали вимогам раціонального використання коштів на рекультивацію та збереження придатності відтворених земель до використання за сільськогосподарським напрямом, як таким, що має найвищі вимоги щодо агрофізичних характеристик грунту.

Методика. У процесі дослідження використано метод теоретичного узагальнення та систематизації (для визначення особливостей формування якісних характеристик техногенного грунту з використанням засобів механізації рекультиваційних робіт), аналітичний (для визначення факторів, що впливають на результативність відтворення земель в умовах відкритих гірничих розробок), порівняння (для аналізу ефективності різних варіантів механізації рекультиваційних робіт).

Результати. Здійснено аналіз впливу технічних засобів механізації рекультиваційних робіт на якість земель, що підлягають відтворенню в умовах відкритих гірничих розробок. Запропоновано методичний підхід до вибору варіанту механізації робіт з рекультивації земель за показниками сформованої якості техногенних земель сільськогосподарського призначення, як чинника їх грошової оцінки, та рівнем витрат на їх відтворення. Розроблено рекомендації щодо управління якістю техногенних земель шляхом технічного забезпечення процесу формування їх споживчих властивостей, скерованого на досягнення сприятливого співвідношення, з одного боку, між якістю та, відповідно, грошовою оцінкою техногенних угідь, а з іншого - витратами на їх відтворення.

Наукова новизна. Запропоновано науково-методичний підхід до вибору технічного устаткування для проведення рекультиваційних робіт, який відрізняється урахуванням двох чинників - витрат на рекультивацію та якість техногенних земель, $і$ дозволяє визначити пріоритетність заощадження витрат або покращення якості земель за цільовим критерієм ефективності рекультиваційних робіт.

Практична значимість. Отримані результати спрямовані на удосконалення методичних основ управління процесом відтворення техногенних земель на основі вибору засобів його механізації.

Ключові слова: якість земель, витрати на рекультивацію, грошова оцінка земель, технологія рекультивації, ефективність рекультивації

\section{Управление качеством воспроизведения земель под сельскохозяйственное использование в условиях открытой горной разработки}

\section{Е. Терехов, Ю. Литвинов, В. Фененко, К. Дребенштедт}

Цель. Теоретическое обоснование принципов и разработка рекомендаций относительно выбора технологического варианта формирования качества земель техногенного происхождения, соответствующего требованиям рационального использования средств на рекультивацию и обеспечения пригодности воспроизводимых земель к сельскохозяйственному использованию, предусматривающему наиболее высокие требования к агрофизическим характеристикам почв. 
Методика. В процессе исследования использованы метод теоретического обобщения и систематизации (для определения особенностей формирования качественных характеристик техногенного грунта с использованием средств механизации рекультивационных работ), аналитический (для определения факторов, влияющих на результативность воспроизводства земель в условиях открытых горных разработок), сравнения (для анализа эффективности различных вариантов механизации рекультивационных работ).

Результаты. Выполнен анализ влияния технических средств механизации рекультивационных работ на качество земель, подлежащих восстановлению в условиях открытых горных разработок. Предложен методический подход к выбору варианта механизации работ по рекультивации земель в зависимости от его влияния на качество техногенных земель сельскохозяйственного назначения как фактора денежной оценки и уровня затрат на их восстановление. Разработаны рекомендации по управлению качеством техногенных земель путем технического обеспечения процесса формирования их потребительских свойств, направленного на достижение благоприятного соотношения, с одной стороны, между качеством и, соответственно, денежной оценкой техногенных угодий, а с другой - затратами на их восстановление.

Научная новизна. Предложен научно-методический подход к выбору технического оборудования для проведения рекультивационных работ, позволяющий на основе учета затрат на рекультивацию и качества техногенных земель определять приоритетность экономии затрат или улучшения качества земель согласно целевому критерию эффективности рекультивационных работ.

Практическая значимость. Полученные результаты направлены на совершенствование методических основ управления процессом восстановления техногенных земель на основе выбора средств его механизации.

Ключевые слова: качество земель, расходы на рекультивацию, денежная оценка земель, технология рекультивации, эффективность рекультивации 